\title{
WOJCIECH SADY*
}

\section{O HISTORYCZNYM ZWIAZZKU MECHANIKI ARYSTOTELESA I MECHANIKI NEWTONA}

\begin{abstract}
ON THE HiSTORICAL RELATIONSHIP BETWEEN ARISTOTLE’S MECHANICS AND NEWTON’s MECHANICS Recently, it has been claimed that Aristotle's mechanics is a special case of Newton's mechanics, adequate for speeds tending to zero (Grygiel 2020). I show in the article that this claim does not stand up to closer scrutiny. But there is a peculiar historical relationship between the two theories. Attempts to reconcile the tenets of Aristotelian mechanics with the results of everyday observations by Greek, Arabic, and Latin commentators led to the addition of the theory of impetus to this mechanics. The theory of impetus, in conjunction with the basic principles of Aristotle's physics, led to conclusions that shattered the system's coherence. In the seventeenth century, some of these conclusions were elevated to the rank of independent principles, and after being separated from their sources, they gave rise to the research program of Newtonian mechanics.

Keywords: Aristotelian physics, impetus theory, classical mechanics, scientific revolution
\end{abstract}

\section{WOJCIECH GRYGIEL O STOSUNKU FIZYKI ARYSTOTELESA DO FIZYKI WSPÓłCZESNEJ}

Wojciech Grygiel w artykule Mechanika arystotelesowska a wspótczesna fizyka. Na tropach ciągłości wewnętrznej logiki rozwoju nauki (2020) twierdzi, że:

między mechaniką arystotelesowską a mechaniką newtonowską działa zasada korespondencji w sensie implikacyjnym, pierwsza teoria jest bowiem szczególnym przypadkiem drugiej (Grygiel 2020: 20).

* Instytut Filozofii i Socjologii, Uniwersytet Pedagogiczny im. KEN w Krakowie, ul. Podchorążych 2, 30-084 Kraków, wojciech.sady@gmail.com, ORCID: https://orcid.org/ ooooooo2-7873-6988. 
Twierdzi też, choć tylko w formie rozproszonych wzmianek, że z kolei mechanika Newtona jest szczególnym przypadkiem teorii względności Einsteina:

I tak: teoria względności to teoria poprawna dla prędkości bliskich prędkości światła, mechanika newtonowska funkcjonuje poprawnie dla prędkości niezerowych, ale dużo mniejszych od prędkości światła, natomiast mechanika arystotelesowska jest adekwatna, gdy prędkość zdąża do zera, czyli gdy ustaje wszelki ruch (Grygiel 2020: 21).

Mamy w artykule zapowiedź metodologicznego programu wysoce abstrakcyjnych badań prowadzonych z użyciem pojęcia wiązek włóknistych:

Podstawową przesłanką istnienia wewnętrznej logiki rozwoju nauki jest niezmienniczość struktury iloczynu kartezjańskiego [...] w wiązkowych reprezentacjach czasoprzestrzennych teorii ruchu od mechaniki Arystotelesa przez mechanikę Newtona do ogólnej teorii względności Einsteina ku przestrzeniom totalnym wiązek, będących coraz bardziej abstrakcyjnymi opisami czasoprzestrzeni (Grygiel 2020: 10).

Takich badań jednak Grygiel nie przeprowadził. Powołał się na prace Michała Hellera na ten temat, ale sam pozostał na poziomie jedynie elementarnych intuicji.

Problem w tym, że materiałem do analizy była dla niego nie fizyka Arystotelesa, w wersji bądź to oryginalnej, bądź przedstawionej przez któregoś z komentatorów greckich, arabskich czy lacińskich, lecz - jak pisze - jej „rekonstrukcja” czy „stylizacja” w języku fizyki współczesnej. Wykorzystuje dwie takie stylizacje, proponowane przez Michała Hellera, kosmologa i filozofa przyrody, oraz Carla Rovellego, fizyka teoretyka o zacięciu filozoficznym. W całym tekście z Arystotelesa są dwa cytaty, zawierające fragmenty pojedynczych zdań. Ważniejszy z nich ma brzmieć: ,cokolwiek jest poruszane, poruszane jest przez coś innego" (Grygiel 2020: 12). Ale we wskazanej partii Fizyki (241b) takiego tekstu nie ma - są inne, podobne, ale mające odmienny sens.

Zajrzyjmy więc sami do Fizyki, O niebie oraz O powstawaniu i niszczeniu, gdzie zawarta jest Arystotelesowska teoria ruchów rzeczy jako zmian zajmowanych przez nie miejsc (jest to tylko jeden z rodzajów zmian określanych słowem kinesis). Dam tu zarys poglądów niby to dobrze znanych, a jednak, o dziwo, przez filozofów (a tym bardziej przez fizyków) zwykle ignorowanych. Nie ma na przykład na te tematy ani słowa w którymś z dwunastu haseł poświęconych Arystotelesowi w The Stanford Encyclopedia of Philosophy, nawet $\mathrm{w}$ haśle o jego filozofii przyrody (Bodnar 2018). Zagadnienia te pominięto też $\mathrm{w}$ dwustustronicowym wprowadzeniu do filozofii Arystotelesa w Historii filozofii starożytnej Giovanniego Realego (1992), mimo że jest tam rozdział zatytułowany „Fizyka”. Postąpię odwrotnie niż Reale: pominę rozważania nad możnością i aktem, przyczynami formalną, materialną, sprawczą i celową, kategoriami substancji, jakości, ilości i miejsca, definicją czasu czy nad nie- 
skończonością. Pozbawię zatem Arystotelesowską fizykę jej tła metafizycznego, a zostawię to, co fizyk rozpozna jako należące do jego dyscypliny. Czy nie będzie to prowadzić do deformacji samej fizyki Stagiryty? W pewnym sensie tak. Na swoje usprawiedliwienie podkreślę, że będzie to deformacja o wiele mniejsza niż ta z prac Hellera, Rovellego i Grygiela. A co ważniejsze, właśnie „fizyczne” treści pobudzily niektórych arystotelesowskich komentatorów do wprowadzenia do fizyki Arystotelesa modyfikacji, które przywiodły ich - jak będę twierdził - na próg fizyki newtonowskiej ${ }^{1}$.

\section{ARYSTOTELES O RUCHACH CIAŁ JAKO ZMIANACH MIEJSC}

W Arystotelesowskim obrazie świat ma kształt kuli, zbudowanej z koncentrycznych sfer, jedna wewnątrz drugiej. Materią sfer jest eter. Sfera zewnętrzna zawiera gwiazdy, a wykonuje pełny obrót wokół osi łączącej północny i południowy biegun nieba w ciągu ok. 23 godzin i 56 minut. Każda z coraz bliższych środkowi sfer przejmuje wirowe ruchy sfery od niej bezpośrednio wyższej i dodaje do tego własny ruch wirowy, z właściwą sobie prędkością i wokół właściwej dla siebie osi. Na niektórych ze sfer znajdują się planety: Saturn, Jowisz, Mars, Wenus, Merkury, Słońce i Księżyc. Ruchy sfer przebiegają zgodnie z matematycznym modelem Eudoksosa z Knidos, rozwiniętym przez Kallipposa z Kyzikos, aby zaś nadać mu sens „fizyczny”, Arystoteles dodał sfery wyrównujące (których użył o sześć za dużo), co łącznie dało 56 sfer.

Pod sferą unoszącą Księżyc znajduje się kulisty „świat podksiężycowy” zbudowany z ciepłego i suchego ognia, ciepłego i wilgotnego powietrza, zimnej i wilgotnej wody oraz zimnej i suchej ziemi. Te cztery elementy w większości ciał są zmieszane w rozmaitych proporcjach. Tak jak Arystoteles nigdzie nie wprowadza ilościowej charakterystyki ciepła/zimna i suchości/wilgoci, tak nie określa proporcji, w jakiej łączą się elementy, poprzestając na twierdzeniach w rodzaju, że metale „są jakby wodą, lecz niezupełnie” (Meteorologika III, 6, 378a). Fizyka dotyczy wyłącznie tego, co dzieje się w świecie podksiężycowym.

Jeśli chodzi o ruchy jako zmiany miejsc, to w perypatetyckiej fizyce są one dwojakiego rodzaju: naturalne i wymuszone. Naturalnymi są np. ruchy zwierząt, choć nie zawsze:

To bowiem, co czerpie ruch z siebie, jak np. wszystkie zwierzęta, porusza się ruchem naturalnym (zwierzę bowiem porusza się wskutek własnego wysiłku); a zawsze wtedy,

${ }^{1}$ Części 2, 3 i 5 przygotowałem m.in. na podstawie (Crombie 1960), (Grant 1996), a także opracowań zawartych w (Jones, Taub 2018) oraz (Lindberg, Shank 2013). Część fragmentów tekstów oryginalnych pochodzi z (Clagett 1955). 
gdy źródło ruchu rzeczy jest w niej samej, mówimy, że ruch tej rzeczy jest naturalny. Z tego przeto względu zwierzę jako całość porusza się ruchem naturalnym; natomiast ciało zwierzęcia może się poruszać zarówno w sposób naturalny, jak i nienaturalny (Arystoteles, Fizyka VIII, 4, 254b).

Zostawmy zwierzęta i przejdźmy do rzeczy nieożywionych, których ruchy są na tyle proste, że Arystoteles formułuje rządzące nimi prawa. Ciała zimne - te, w których przeważają elementy ziemi i wody, nawet jeśli z naszego punktu widzenia ich temperatura jest akurat wysoka - mają swe „miejsce naturalne” w środku świata. „Dążą” do tego środka, a ziemia czyni to intensywniej niż woda. Z kolei ciała ciepłe - w których przeważają ogień i powietrze - dążą w górę, ku sferze Księżyca. Ogień dąży tam najintensywniej.

Ruch naturalny następuje w zależności od miejsca, jakie zajmuje dane ciało, a także od tego, czy natrafia ono na przeszkodę. Miejsce, wbrew temu, jak nauczono nas myśleć, jest określone nie geometrycznie, ale jako „granica ciała otaczającego, będącego w styczności z ciałem otaczanym” (Fizyka IV, 4, 212a). Jeśli na przykład ciało, w którym przeważa ziemia, otacza woda, powietrze bądź ogień, a od dołu (od strony środka świata) nie natrafia ono na przeszkodę, to porusza się w dół; natomiast ogień otoczony przez wodę lub powietrze ruchem naturalnym porusza się w górę. I tak dalej.

Zmiana miejsca ciał naturalnych, takich np. jak ogień, ziemia itp., wykazuje nie tylko to, że miejsce jest czymś, ale i to, że wywiera ono pewien wpływ; mianowicie każde ciało elementarne dąży do właściwego sobie miejsca, jeśli tylko nic nie stanie mu na przeszkodzie: jedno do góry, inne na dół (Arystoteles, Fizyka IV, 1, 208b).

A oto prawa rządzące ruchami naturalnymi:

obserwacja poucza, że ciała, które mają przewagę bądź w ciężarze, bądź w lekkości, a są podobne pod innym względem, przebiegają szybciej równą przestrzeń, w proporcji takiej, w jakiej pozostają do siebie ich wielkości (Arystoteles, Fizyka IV, 8, 216a).

Niechaj ciało $A$ porusza się przez ośrodek $B$ w czasie $\Gamma$ i przez o wiele rzadszy ośrodek $\Delta$ w czasie $E$; jeżeli $B$ i $\Delta$ będą równe pod względem długości, to czas poruszania się ciała $A$ będzie proporcjonalny do oporu ośrodka. [...] Jeżeli więc powietrze jest dwa razy rzadsze od wody, wobec tego ciało potrzebuje na przejście ośrodka $B$ dwa razy więcej czasu w stosunku do tego, ile by potrzebowało na przejście ośrodka $\Delta$ (Arystoteles, Fizyka IV, 8, 215b).

Ma to obowiązywać również dla ruchów naturalnych w górę: „[...] większa ilość ognia porusza się zawsze prędzej ku górze niż mniejsza jego ilość” (O niebie IV, 2, 309b). Arystoteles tu i ówdzie dodaje uwagi, że na szybkość mają też wpływ kształty ciał (por. np. O niebie IV, 6, 313a-b), ale nigdzie tego zagadnienia nie rozwija.

Choć w tych tekstach nie używa się pojęcia prędkości jako stosunku drogi do czasu - czytamy o czasie, w jakim ciało przebędzie daną drogę, lub o dro- 
gach przebytych $\mathrm{w}$ danym czasie - to bez popadania w zbytni zamęt można uogólnić przytoczone twierdzenia do postaci formuły: prędkość, z jaką ciało spada ruchem naturalnym, jest proporcjonalna do jego ciężaru, a odwrotnie proporcjonalna do oporu ośrodka.

Wskutek tych naturalnych dążności wokół środka świata uformowała się kula zbudowana $\mathrm{w}$ większości z ziemi, z wodą gromadzącą się na jej powierzchni, otoczona przez powietrze, nad którym, w styczności ze sferą księżycową, zgromadził się ogień. Gdyby świat podksiężycowy pozostawić samemu sobie, po pewnym czasie nastąpiłoby rozdzielenie elementów. Że tak nie jest, że wszystko pod Księżycem zmienia się od zawsze i zawsze będzie się zmieniać, zawdzięczamy niebu, a zwłaszcza Słońcu. Jako zbudowane z eteru nie jest ono wprawdzie gorące, ale jego obecność w górze sprawia, że to, co było zimne, ogrzewa się, a to, co było wilgotne, staje się suche. Gdy zaś Słońca brak, to rzeczy suche wilgotnieją, a ciepłe stają się zimne. W rezultacie tych procesów powietrze staje się ogniem lub wodą, woda ziemią lub powietrzem, ziemia ogniem lub wodą, a ogień ziemią lub powietrzem. Po takiej przemianie ciało znajduje się w miejscu dla siebie nienaturalnym i, jeśli nie natrafi na przeszkodę, porusza się ruchem naturalnym w górę lub w dół.

Jeżeli zatem wszystkie rzeczy poruszające się albo się poruszają ruchem naturalnym, albo przeciw naturze i wymuszonym, i jeżeli wszystkie rzeczy, których ruch jest wymuszony i nienaturalny, są poruszane przez czynnik zewnętrzny; jeżeli dalej wszystkie rzeczy, których ruch jest naturalny, są również poruszane przez czynnik zewnętrzny - zarówno te, co się poruszają same, jak i te, które się same nie poruszają (np. rzeczy lekkie i ciężkie: zostały wszak poruszone albo przez to, co je takimi uczyniło, albo przez to, co usunęło przeszkodę ich ruchu) - to wszystkie rzeczy będące w ruchu musiały być poruszone przez czynnik zewnętrzny (Arystoteles, Fizyka VIII, 4, 255b-256a).

Wieczne ruchy kołowe sfer niebieskich nie podlegają prawom fizyki ziemskiej. Związane z tym spekulacje z VIII księgi Fizyki i XII księgi Metafizyki o miłości do nieruchomego Pierwszego Poruszyciela, która wprawia w ruch sfery, można tu pominąć.

Ciało porusza się ruchem wymuszonym, gdy działa na nie siła. Tę wywierać może tylko inne ciało, które z ciałem rozważanym pozostaje $\mathrm{w}$ styczności (o czym pouczają codzienne obserwacje). Wymuszone są wszystkie ruchy ciał nieożywionych w kierunkach poziomych, a także ruchy ziemi i wody w górę, a ognia i powietrza w dół. Przynajmniej dla ruchów w poziomie obowiązywać mają następujące prawa:

Niechaj $A$ będzie czynnikiem poruszającym, $B$ rzeczą poruszaną, $\Gamma$ odległością pokonywaną, a $\Delta$ czasem, w którym ruch się dokonał; wobec tego w tym samym czasie ta sama siła $A$ poruszy $1 / 2 B$ na drodze $2 \Gamma$, w czasie $1 / 2 \Delta$ poruszy $1 / 2 B$ na całym odcinku drogi $\Gamma$; w ten bowiem sposób da się ustalić proporcja. A jeżeli ta sama siła porusza to 
samo ciało w pewnym czasie na pewnej przestrzeni, i na połowie tej przestrzeni w połowie czasu, to połowa siły poruszającej będzie poruszać połowę ciała na takiej samej przestrzeni w tym samym czasie (Arystoteles, Fizyka VII, 5, 250a).

Naturalnym uogólnieniem tych uwag jest formuła, zgodnie z którą prędkość, z jaką ciało porusza się ruchem wymuszonym, jest proporcjonalna do działającej siły, a odwrotnie proporcjonalna do ciężaru ciała. Nie jest to jednak takie proste, ponieważ Arystoteles zaraz potem podkreśla, że zdarza się, iż siła „nie spowoduje w ogóle żadnego ruchu” (VII, 5, 250a), np. siła wywierana przez jednego człowieka nie poruszy okrętu. A jednak w Fizyce i innych pismach trudno znaleźć uwagi na temat roli ośrodka w przypadku ruchu wymuszonego, które pozwalałyby odróżnić, na przykład, ruch wymuszony w powietrzu od ruchu w wodzie, albo wyjaśnić różnicę między sytuacją, w której dana siła działa na skrzynię leżącą na ziemi, a sytuacją, w której ta sama siła działa na identyczną skrzynię umieszczoną na kołach. Nie wiemy, czy Arystoteles nad takimi zjawiskami się nie zastanawiał, czy też pewne teksty nie przetrwały do czasów Andronikosa z Rodos. W ogóle nie jest jasne, czy Arystoteles chciał sformułować coś, co nazwalibyśmy „prawami ruchu” - niemniej tak jego rozproszone uwagi odczytywali interpretatorzy.

Zastanawiał go natomiast inny problem. $\mathrm{Z}$ tego, co dotąd powiedziano, wynika, że na przykład wystrzelona $\mathrm{z}$ łuku w górę strzała zatrzyma się natychmiast po utracie kontaktu $\mathrm{z}$ cięciwą, a potem spadnie ruchem naturalnym w dół. A w przypadku strzały wystrzelonej poziomo wymuszony ruch w chwili oderwania się strzały od cięciwy zamieni się na naturalny spadek w pionie. Pozostaje to w oczywistej sprzeczności z wynikami codziennych obserwacji. Arystoteles stwierdził w związku z tym:

ciała rzucone poruszają się, chociaż nie mają już kontaktu ze źródłem impulsu. A poruszają się albo wskutek kolejnej zmiany miejsca, jak twierdzą, albo wskutek tego, że wprawione w ruch powietrze popycha ciało ruchem szybszym od jego naturalnego ruchu, ku właściwemu miejscu (Arystoteles, Fizyka IV, 8, 215a).

Co znaczy „kolejna zmiana miejsca”? Sformułowane wyżej prawa Arystoteles wykorzystuje, aby dowieść nieistnienia próżni. Jego argumentację tutaj pominę. Skoro zaś cała przestrzeń jest wypełniona ciałami, to nie istnieją ruchy inne niż przez taki bądź inny ośrodek. W trakcie ruchu nie tylko ciało $\mathrm{X}$ zmienia miejsce, lecz następuje zamiana miejsc. Ośrodek wypełnia miejsce za poruszającym się ciałem, a wypełniając je, popycha ciało w kierunku ruchu. Mamy tu osobliwe rozdwojenie. Ośrodek znajdujący się przed X-em - tak przynajmniej Arystoteles ujmował to w przypadku ruchów naturalnych - spowalnia ruch $\mathrm{X}-\mathrm{a}$, podczas gdy ten sam ośrodek za X-em jego ruch podtrzymuje. 
W tym samym fragmencie mamy też alternatywne rozwiązanie: sprawca ruchu porusza nie tylko X-a, lecz także otaczający ośrodek, a w rezultacie tego powstaje ruch powietrza czy wody, który popycha X-a z prędkością większą od tej, z którą X, nie natrafiając na przeszkodę, spadałby ku miejscu naturalnemu. Jeśli wystrzelona poziomo strzała $\mathrm{w}$ końcu spada, to zapewne (nie mamy uwag Arystotelesa na ten temat) dlatego, że powiew wytworzony przez cięciwę słabnie z odległością.

\section{PRÓBY MATEMATYZACJI ARYSTOTELESOWSKICH PRAW RUCHU}

Dwa wspomniane prawa ruchu budzą wiele wątpliwości, z którymi musieli zmierzyć się komentatorzy. Po pierwsze, zawarte w nich uwagi o proporcjach sugerują, że mają one charakter ilościowy. Byłoby tak jednak wtedy, gdyby Arystoteles podał jakiś sposób określania gęstości ośrodka, siły i innych wielkości. Po drugie, nie jest bynajmniej jasne, jak „proporcje” rozumieć. Nam narzuca się użycie ułamka i zapisanie dla ruchów naturalnych:

$$
v \sim \frac{Q}{R}
$$

gdzie $v$ to prędkość, $Q$ to ciężar, $R$ to opór ośrodka. Dla ruchów wymuszonych narzuca się:

$$
v \sim \frac{F}{Q}
$$

gdzie $F$ to siła. Jednak wielu komentatorów takich formuł nie proponowało, zwłaszcza dlatego, że z (2) wynika, iż dowolnie mała siła wprawi ciało w ruch, co przeczy codziennym obserwacjom. Było też oczywiste, że trzeba jakoś połączyć oba prawa. Ruchy wymuszone dokonują się m.in. w pionie, a wtedy siła zewnętrzna jakoś „sprzeciwia się” ciężarowi lub z nim „współpracuje”. Wprawdzie przez długie wieki sądzono, że ciało wykonywać może tylko jeden rodzaj ruchu i gdy na przykład opisywano ruch rzuconego kamienia, to jako ruch najpierw wymuszony przez czynnik zewnętrzny, a gdy ten czynnik ustawał, jako ruch naturalny pionowo w dół. Dopiero w XIV w. niektórzy zaczęli opisywać faktyczny ruch jako złożenie jego obu rodzajów. Jeśli zaś chodzi o ruchy wymuszone w kierunku poziomym, to było oczywiste, że ich prędkość zależy również - podobnie jak w przypadku ruchów naturalnych - od oporu ośrodka, a nie tylko od ciężaru. Czasem dla danego ciała zapisywano: 
(3)

$$
v \sim \frac{F}{R}
$$

To też prowadziło do wniosku, że ruch będzie trwał przy dowolnie małej sile. Aby tej konsekwencji uniknąć, Awempace (Ibn Badżdża) w XII w. zaproponował inną „proporcje”:

$$
v \sim F-R \text {. }
$$

Zgodnie z tym równaniem ciało miałoby skończoną prędkość w próżni, gdzie $R=0$. Tym samym jeden z głównych argumentów Arystotelesa za nieistnieniem próżni upadał ${ }^{2}$. Do XV w., warto dodać, w matematyce nie było liczb ujemnych, w związku z czym nie powstawało pytanie, czy ciało miałoby prędkość ujemną, gdyby opór przewyższył siłę.

Tomasz Bradwardine w ogłoszonym w pierwszej połowie XIV w. De proportionibus velocitatum in motibus odrzucił obie podane wyżej formuły i zaproponował zależność, którą dziś zapisalibyśmy jako:

$$
v \sim \log \left(\frac{F}{R}\right)
$$

Ponieważ $\log 1=0$, to ruch następuje jedynie wtedy, gdy siła przewyższa opór. Dla siły mniejszej od oporu wartość logarytmu byłaby ujemna, ale Bradwardine - który przecież logarytmów nie znał - przejmować się tym nie musiał.

Prowadzono też inne rozważania na temat ruchów ciał. W pierwszej połowie XIV wieku tzw. kalkulatorzy oksfordzcy, Wilhelm Heytesbury, Jan Dumbleton i Ryszard Swineshead próbowali, nie dysponując rachunkiem różniczkowym, zdefiniować prędkość chwilową i przyspieszenie. W tym samym czasie prowadzono rozważania na temat oporu wewnętrznego: element w ciele dominujący miał powodować jego ruch naturalny w górę lub w dół z właściwą dla siebie prędkością, czemu opór stawiałyby pozostałe zawarte w ciele elementy. Niektórzy twierdzili na tej podstawie, że w próżni ciała spadałyby z ograniczoną prędkością, tą samą dla ciał o identycznym składzie, a niezależną od ich ciężarów. Choć ten wniosek był niezgodny z cytowaną opinią Arystotelesa, to tego typu teorie formułowane były w jego języku, a zasada, że wszystko, co się porusza, jest przez coś poruszane, pozostawała nienaruszona. Wierność arystotelesowskiej tradycji przejawiała się też w tym, że tym i innym dociekaniom nie towarzyszyły badania eksperymentalne, które by takie twierdzenia potwierdziły bądź sfalsyfikowały, a przede wszystkim nadały im charakter ilościowy.

\footnotetext{
${ }^{2}$ Tego wzoru używał Tomasz z Akwinu, a także Galileusz w jednej ze swych wczesnych prac.
} 


\section{STYLIZACJE MECHANIKI ARYSTOTELESA ZAPROPONOWANE PRZEZ HELLERA, ROVELLEGO I GRYGIELA}

Możemy teraz porównać fizykę Arystotelesa ze „stylizacjami”, z których korzysta Grygiel. Pierwsza z nich, dokonana przez Hellera (1993: 25-26), zawiera się w jednym równaniu:

$$
v=\frac{F}{m} \text {. }
$$

Zarówno prędkość, jak i siła, a także $m$ - masa, mają być rozumiane po newtonowsku (choć przy takim zapisie prędkość miałaby wymiar przyspieszenia). Ale (6) nie jest równaniem mechaniki arystotelesowskiej, również jako jej „stylizacja”. Nie obejmuje ruchów naturalnych - w tym przypadku, jeśli chcemy „rekonstruować” ciężar jako masę, masa powinna znaleźć się w liczniku, a nie w mianowniku. Dziwne jest traktowanie (6) jako równania ruchu w ośrodku stawiającym opór - bo właśnie o oporze nie ma tam mowy. A przecież opór był jednym z głównych składników Arystotelesowskiej teorii ruchów. Nie rozumiem, co pozwoliło pominąć go w „stylizacji”.

Pominięcie ośrodka ma poważną konsekwencję. Wystarczy rzucić kamieniem, by zobaczyć to, co natychmiast sfalsyfikuje (6): kamień nie nieruchomieje po utracie kontaktu z dłonią, by chwilę potem spaść pionowo w dół. Arystoteles, o czym była mowa wyżej, twierdzil, że w takich przypadkach to ośrodek przez jakiś czas utrzymuje ciało w ruchu wymuszonym. Oczywiście, nikt dziś nie uznaje tego wyjaśnienia za poprawne, niemniej jakieś wyjaśnienie to było. Grygiel za Hellerem to wyjaśnienie usuwa - i jako „rekonstrukcję” mechaniki Arystotelesa proponuje teorię w jawny sposób przeczącą wynikom codziennych obserwacji.

Twierdzi, najwyraźniej w związku z tą deformacją (a nie stylizacją), że mechanika ta jest poprawna dla przypadków, gdy - przy braku sił - ruch ustaje (Grygiel 2020: 21). W ten sposób deformacje mnoży: gdy zewnętrzne siły nie działaja, to $\mathrm{w}$ Arystotelesowskim obrazie świata ruchy jako zmiany miejsc wciąż trwają, a są to ruchy naturalne. Trwałyby one również wtedy, gdyby $\mathrm{w}$ świecie podksiężycowym przestały działać wszelkie siły: elementy nadal przeobrażałyby się jedne w drugie wskutek ruchu Słońca, a powstające w ten sposób rzeczy wędrowałyby w górę i w dół. Konie biegałyby po łąkach, a ryby pływały w rzekach.

Przejdźmy do tekstu Rovellego. Nie próbuje on podstawiać za formuły Arystotelesa ich współczesnych „rekonstrukcji”, ale buduje newtonowski model ruchów ciał w ośrodku stawiającym opór w pobliżu powierzchni Ziemi. 
Podstawowe równanie - po dokonaniu niewielkich przybliżeń - ma w analizowanym przypadku postać:

$$
m \boldsymbol{a}=-m g \mathbf{z}+V \rho \mathbf{z}+C \rho|v| \boldsymbol{v}+\boldsymbol{F}_{\text {zewn }}
$$

gdzie $m$ - masa, $\boldsymbol{a}$ - przyspieszenie, $g-$ przyspieszenie ziemskie, $\mathbf{z}-$ jednostkowy wektor wskazujący pionowo w górę, $V$ - objętość ciała, $\rho$ - gęstość ośrodka, $C$ - współczynnik zależny od wielkości i kształtu ciała, $v$ - prędkość ruchu ciała. Pierwszy człon po prawej stronie równania opisuje siłę grawitacji, drugi siłę wyporu, trzeci siłę oporu ośrodka. $\boldsymbol{F}_{\text {zewn }}$ to przyłożona z zewnątrz siła, odpowiednik siły, o której pisze Arystoteles.

Rovelli rozważa konsekwencje (7) z zamiarem wykazania, że teoria Arystotelesa - wbrew powszechnej opinii współczesnych fizyków - jest „oparta na obserwacjach i poprawna (w swoim zakresie obowiązywania) w tym samym sensie, w jakim fizyka Newtonowska jest poprawna (w swoim zakresie)" (2015: 24). Z (7) wynika, że ciało spadające swobodnie po pewnym czasie - gdy opór ośrodka zrówna się z ciężarem - będzie poruszać się ruchem jednostajnym z szybkością a) proporcjonalną do jego ciężaru, b) zależną od rozmiarów i kształtu ciała oraz c) zależną od rodzaju ośrodka, w którym spadanie zachodzi. Konsekwencje a) i c) zgadzają się, zauważa Rovelli, z Arystotelesowskimi prawami ruchów naturalnych, o b) też Arystoteles wspominał. Jest to główny przykład zgodności między obiema teoriami ruchów, jaki da się w tekście Rovellego znaleźć. Zastanówmy się nad zasadnością twierdzeń włoskiego fizyka.

Arystoteles nie prowadził eksperymentów. Nie prowadzili ich też jego greccy, arabscy i łacińscy komentatorzy. Wszyscy oni przykłady zjawisk czerpali jedynie z codziennych obserwacji. Jakie zjawiska mogli brać pod uwagę? Na pewno nie spadek kamienia wypuszczonego z wysoka przez ptaka albo spadek kawałka metalu w wodzie - by stwierdzić, że te ciała szybciej czy później zyskują jednostajną prędkość. A właśnie te przypadki przywołuje Rovelli. Tymczasem dla Arystotelesa i komentatorów podstawą do rozważań była obserwacja swobodnych spadków ciał $\mathrm{w}$ powietrzu z wysokości nie większej niż jakieś trzydzieści metrów. Takie ruchy są - jak to wynika z (7) i wiedzy towarzyszącej o ciężarach właściwych i oporze powietrza w zależności od prędkości - dla kamieni czy brył metalu niemal jednostajnie przyspieszone. Falsyfikują one (1). Wbrew uwagom Rovellego, ruchy te nie są aż tak szybkie, aby zachodzenie przyspieszenia nie dało się stwierdzić. Zdołał to uczynić Straton z Lampsakos już w III w. p.n.e. Faktycznie, pióro ptasie - ciało o niewielkim ciężarze spada z prędkością niewielką i niemal od razu stałą, a kamień spada z tej samej wysokości w czasie o wiele krótszym. Ale jeśli weźmiemy dwa kuliste kamienie, z których jeden waży na przykład 1 kilogram, a drugi 10 kilogramów i pozwolimy im spadać z wieży z prędkością początkową równą zeru, to stwierdzimy, że ude- 
rzą w ziemię w tej samej chwili - a w każdym razie nie będzie łatwo dostrzec różnicy czasów spadania. Podsumowując, te ruchy naturalne ciał nieożywionych, które przede wszystkim mieli na myśli Arystoteles i komentatorzy - a nie te, które przywołuje Rovelli - przebiegają zgodnie z mechaniką klasyczną w sposób radykalnie różny od sposobu „arystotelesowskiego”.

Równie wadliwe - a o wiele bardziej lapidarne - są uwagi Rovellego na temat ruchów wymuszonych. Pominę je z braku miejsca. Na to zaś, co włoski fizyk pisze o ruchach ciał niebieskich w arystotelesowskim obrazie świata, lepiej spuścić zasłonę milczenia. Trzeba przyznać, że § IV swojego artykułu poświęca słabościom mechaniki Arystotelesa - choć na koniec znów jej broni.

Jednak nie z Rovellim chciałem tu polemizować. Osobliwe jest to, że przypadki zgodności mechaniki Arystotelesa z mechaniką Newtona w jej zastosowaniu do ciał poruszających się w ośrodkach stawiających opór dotyczyły ciał będących $\mathrm{w}$ ruchu, w dodatku (jak przywołany przypadek kamienia upuszczonego z wysoka przez ptaka) z dość dużymi prędkościami. Tymczasem Grygiel powołuje się na Rovellego, by twierdzić, że mechanika Arystotelesowska jest słuszna dla ciał nieruchomych. Jego twierdzenie, że między obiema mechanikami zachodzi „zasada korespondencji w sensie implikacyjnym” pozostaje bezzasadne.

\section{KOMENTATORZY ARYSTOTELESOWSCY O NABYTEJ SILE WEWNĘTRZNEJ}

A jednak fizyka Arystotelesa odegrała zasadniczą rolę w procesie narodzin mechaniki Newtona. Uświadomily to nam przed z górą stu laty prace Pierre'a Duhema (zwłaszcza Duhem 1913-1959). Już po śmierci francuskiego fizyka, filozofa i historyka nauki w 1916 r. jedni jego tezy rozwijali, inni - jak Alexandre Koyré - krytykowali. Nie miejsce tu, aby te dyskusje omawiać. Zamiast tego $\mathrm{w}$ wielkim skrócie pokażę najważniejsze kroki wiodące od Arystotelesa do Newtona.

Straton z Lampsakos, scholarcha Liceum w latach od ok. 286 do 269 p.n.e., zauważyl, że strumień spadającej wody zwęża się wraz z przebytą drogą i że siła, z którą uderza spadający kamień, jest tym większa, z im większej wysokości spadł - z czego wywnioskowal, że ruchy ciał spadających są przyspieszone. Argumentował też, że próżnia może istnieć. Szczegółów jego prac nie znamy.

Sto lat później zagadnienia ruchów ciał rozważał Hipparch z Nikai. Znów bardzo niewiele o tym wiemy, niemniej komentator arystotelesowski, Symplicjusz (Simplikios) z Cylicji, w VI w. relacjonował: 
Hipparch w książce $O$ ciałach poruszanych $w$ dót przez własny ciężar powiada, że w przypadku ziemi rzuconej w górę miotająca siła jest przyczyną ruchu wznoszącego dopóty, dopóki jest silniejsza niż moc rzuconego ciała; im większa jest siła miotająca, tym szybciej przedmiot porusza się w górę. Następnie, w miarę jak ta siła się zmniejsza, ruch w górę trwa z prędkością malejącą, aż wreszcie ciało zaczyna poruszać się w dół pod wpływem własnego naturalnego impulsu, choć siła wyrzucająca w pewien sposób trwa; w miarę jak ona słabnie, ciało porusza się w dół coraz szybciej, osiąga zaś prędkość największą, gdy ta siła znika całkowicie. Przypisuje też tę samą przyczynę ciałom upuszczonym z wysoka. Gdyż w ich przypadku siła, która je utrzymywała, trwa przez czas jakiś, a jej przeciwne działanie jest przyczyną, dla której spadające ciało na początku porusza się wolniej (Symplicjusz, In Aristotelis De caelo 264, 25; cyt. wg Clagett 1955: 543).

Najwyraźniej Hipparch odrzucał Arystotelesowską teorię poruszającej mocy powietrza. Nie wiemy, na jakiej podstawie. W zamian twierdzil, że siła miotająca na pewien czas pozostaje $\mathrm{w}$ poruszonym ciele, napędzając je niejako od wewnątrz. Ta hipoteza wyjaśniała też, dlaczego naturalny ruch ciał jest w początkowej fazie przyspieszony. Według Newtona, zauważmy, przyspieszenie jest skutkiem stałego działania siły na poruszające się ciało, według Hipparcha zaś miało być wywołane stopniowym zanikiem siły, która działała na ciało, nim ruch się rozpoczął.

Cytowany przed chwilą Symplicjusz bronił poglądu Arystotelesa, że ruch wymuszony zawsze powodowany jest przez czynnik zewnętrzny, i twierdzil, że ruch trwa w wyniku wzajemnego oddziaływania pocisku i powietrza. Jeśli o naturalny spadek chodzi, to dodawał, że wzrost prędkości ciała spadającego wywołany jest tym, że w miarę zbliżania się do środka świata jego ciężar rośnie.

W połowie II w. p.n.e. militarna ekspansja Rzymu unicestwiła naukę hellenistyczną. Na kolejny krok w rozwoju teorii ruchów ciał trzeba było czekać siedem stuleci. Dokonał go w połowie VI w. n.e. komentator arystotelesowski i chrześcijański teolog, Jan Filoponus. Argumentował m.in., że gdyby popchnięte na przykład przez dłoń miotającą kamień powietrze miało podtrzymywać ruch kamienia, to można by kamień poruszyć bez dotykania go, a jedynie uderzając $\mathrm{w}$ powietrze tuż za nim - a temu doświadczenie przeczy. Filoponus trwał natomiast przy głównej zasadzie Arystotelesa, zgodnie z którą wszystko, co się porusza, jest przez coś poruszane. Skoro pocisku nie porusza powietrze, to jest on poruszany przez siłę wewnętrzną. Tej siły nie było, gdy kamień leżał nieruchomo, a zatem została mu ona nadana przez pierwotnego sprawcę ruchu.

Musi być raczej tak, że rzucający przekazuje rzucanemu przedmiotowi pewną bezcielesną siłę kinetyczną i że popchnięte powietrze nie wnosi nic do tego ruchu lub wnosi bardzo niewiele. Jeśli zatem siła porusza w ten sposób przedmioty, to jest jasne, że jeśli strzała lub kamień zostaną ciśnięte siłą wbrew naturze w próżni, to to samo stanie się o wiele łatwiej, a wszystko będzie zbędne prócz rzucającego (Filoponus, In Aristotelis Physicam 641, 29; cyt. wg Clagett 1955: 546). 
Powtórzywszy tu w zasadzie znaną nam już koncepcję Hipparcha, Filoponus opowiedział się też za możliwością istnienia próżni. Jedyną teraz, zauważmy, rolą ośrodka jest stawianie oporu poruszającemu się w nim ciału. Filoponus odrzucał też Arystotelesowskie prawa rządzące ruchami naturalnymi. Twierdzenie, że czas spadania z danej wysokości jest odwrotnie proporcjonalny do ciężaru ciała, jest:

zupełnie błędne, czego lepiej dowodzą same fakty niż rozumowanie teoretyczne. Jeśli bowiem równocześnie upuści się z tej samej wysokości dwa bardzo różne ciężary, to stwierdzi się, iż stosunek czasów trwania ruchu nie jest równy stosunkowi ciężarów, ale że różnica tych czasów jest bardzo niewielka (Filoponus, In Aristotelis Physicam 683, 16; cyt. wg Clagett 1955: 433).

Filoponus, a także Symplicjusz, działali w czasach, gdy Justynian Wielki likwidował resztki stylów myślowych rozwiniętych przez starożytnych Greków. Grecka spuścizna stała się w X w. własnością świata islamu. Mieszając, zrazu nieświadomie, wątki platońskie i arystotelesowskie, piszący po arabsku uczeni dokonali pierwszych prób matematyzacji wyłożonych wyżej praw ruchów ciał.

Idee Filopona przejął na początku XI w. Awicenna. Tak oto pisał w Księdze uzdrowienia o obu wspomnianych teoriach poruszającej mocy powietrza i o teorii siły nabytej:

Dla przypadku, kiedy następuje [ruch wymuszony i] oddzielenie ciała poruszającego się, na przykład pocisku lub ciała toczącego się [od czynnika poruszającego], uczeni mają opinie rozbieżne. Niektórzy uważają, że przyczyna leży w skłonności powietrza, które zostało popchnięte, by znaleźć się za pociskiem i zjednoczyć się tam z siłą, która naciska na to, co jest z przodu. Inni mówią, że czynnik poruszający popycha razem powietrze i pocisk, ale powietrze, bardziej podatne na popychanie, popychane jest prędzej, więc pociąga to, co w nim jest zawarte. Są też tacy, którzy utrzymują, że przyczyna jest w sile, którą ciało poruszające się nabywa od czynnika poruszającego i która w nim pozostaje, dopóki nie zostanie zniweczona przez przeciwstawiającą się siłę tego ośrodka, który ciała dotyka i jest przezeń przemieszczany. I kiedy ta siła słabnie, naturalna skłonność i działanie tarcia zaczynają nad nią przeważać, siła więc niknie i pocisk zaczyna się poruszać w kierunku wyznaczonym przez jego naturalną skłonność. Stwierdziliśmy, że najsłuszniejszą opinię głoszą ci, którzy utrzymują, że ciało poruszające się otrzymuje skłonność od czynnika poruszającego (Awicenna, Kitab asz-Szifa, cyt. wg Wróblewski 2006: 61).

Zauważmy, że Awicenna wspomniał jedynie o obu znanych nam już teoriach poruszającej mocy powietrza i o teorii siły nabytej. Najwyraźniej innych na rynku idei nie było bądź odgrywały rolę marginalną. Zgodnie ze wzorem (3) twierdzil, że prędkość, jaką uzyskuje ciało pod działaniem danej siły, jest odwrotnie proporcjonalna do ciężaru. 
W XII w. poglądy Awicenny na ruchy ciał krytykował Awerroes, bezwzględnie wierny Arystotelesowi. Pominę jego poglądy, wspomnę tylko, że Bradwardine przypisywał mu prawo ruchu:

$$
v \sim \frac{(F-R)}{R} .
$$

Wyjaśniało ono, dlaczego siła mniejsza od oporu w ogóle ciała nie poruszy.

W ciągu XII w. uczeni rzymskokatolickiej Europy uzyskali dostęp do łacińskich przekładów pism przyrodniczych Arystotelesa, a także do tłumaczeń niektórych greckich i arabskich komentarzy. Zaczęły powstawać komentarze lacińskie, dotyczące m.in. natury ruchów ciał i praw nimi rządzących. Trudno uporządkować gąszcz koncepcji, jakie na te tematy pojawiły się w ciągu XIII i XIV w. Spierano się o istnienie próżni i o to, jak ruchy w niej by przebiegały. Nie próbowano przy tym tych i innych sporów rozstrzygać na podstawie systematycznie prowadzonych badań eksperymentalnych. Powoływano się jedynie, podobnie jak robil to sam Arystoteles, na zjawiska znane z codziennego doświadczenia, a w dodatku dobierano te, które zdawały się potwierdzać daną koncepcję, a ignorowano pozostałe.

Prac Filopona - wyjąwszy uwagi polemizującego z nim Symplicjusza i Awicenny o sile nabytej prawdopodobnie nie znano, niemniej na początku XIV w. Franciszek z Marchii pisał o pocisku, który porusza się pod wpływem siły, jaką pozostawil w nim pierwotny sprawca ruchu. Wpłynął on zapewne na Jana Buridana, którego komentarz do Fizyki Arystotelesa, powstały w połowie XIV w., miał przyćmić inne prace na te tematy.

Buridan, co trzeba na początek podkreślić, w pełni akceptował główną zasadę Arystotelesa, że wszystko, co się porusza, jest przez coś poruszane. Za Arystotelesem przyjmował także, że trwanie ruchu wymuszonego wymaga stałego działania siły. Ale przywołał przy tym zjawiska, których nie da się pogodzić z obu wersjami teorii poruszającej mocy powietrza. Pierwsza z nich, jak już wiemy:

wskazuje, że przedmiot rzucany szybko opuszcza miejsce, w którym był, a natura nieznosząca próżni szybko wypełnia to miejsce powietrzem [...] to powietrze, które w ten sposób zostało szybko wprawione w ruch, stale dotyka przedmiotu rzucanego, popychając go dalej na pewną odległość (Buridan 2000: 268).

Pierwszym zjawiskiem falsyfikującym, które przywołuje Buridan, jest ruch wirowy tarczy, który trwa, choć ciało żadnego miejsca nie opuszcza. Drugie to ruch włóczni, której koniec zaostrzono, a porusza się ona nie gorzej od takiej z końcem tępym - a przecież „powietrze, które wypełnia próżnię powstałą po włóczni, nie może w ten sam sposób wprawiać w ruch przedmiotu ostrego 
i nieostrego, ponieważ jest ono latwiej rozdzielane przez ostry [przedmiot]" (Buridan 2000: 269). Żeglarz stojący na pokładzie szybko płynącego okrętu nie czuje zaś siły, która pchałaby go ku dziobowi, a „czuje jedynie opór powietrza na twarzy" (Buridan 2000: 269). Druga teoria mówi o popychaniu ciała przez powietrze wprawione w ruch przez początkowego poruszyciela. Ale jeśli okryjemy wirujące koło młyńskie tkaniną albo rozwiesimy tkaninę za rufą rozpędzonego okrętu, nie zatrzyma to ich ruchu. A gdy na pokładzie okrętu leży sterta siana, to widzimy, że źdźbła zginają się nie do przodu, ale do tyłu. Powietrze nie porusza więc cial, ale ich ruchowi stawia opór. I tak dochodzimy do najważniejszego fragmentu Buridanowskiego komentarza (w przytoczonych fragmentach zmieniam używany przez polskich tłumaczy „impet” na „impetus”):

Dlatego, jak sądzę, trzeba powiedzieć, że w chwili poruszania czegoś dającego się poruszyć, poruszyciel wtłacza w nie pewien impetus, czyli pewną siłę poruszania skierowaną w tę stronę, w którą porusza je poruszyciel, czy to do góry, czy do dołu, czy w bok, czy dookoła. A im szybciej poruszyciel porusza owo ciało podlegające ruchowi, tym silniejszy wtłacza weń impetus. Dzięki temu impetusowi kamień porusza się również wtedy, gdy osoba rzucająca przestaje go poruszać. Lecz ów impetus zmniejsza się ciągle z powodu oporu powietrza i ciężaru kamienia przeciwstawiających się ruchowi nadawanemu przez impetus. Stąd ruch owego kamienia staje się coraz wolniejszy, aż do momentu zmniejszenia albo zaniku impetusu tak, że ciężar kamienia spowoduje ruch kamienia na dół, ku naturalnemu miejscu (Buridan 2000: 272).

Choć tekst nie jest precyzyjny, to prawo Arystotelesa, zgodnie z którym szybkość ruchów wymuszonych jest proporcjonalna do siły, każe Buridanowi przyjąć, że impetus jest proporcjonalny do prędkości. Zaraz dalej czytamy, że skoro, jak poucza nas doświadczenie, ruch ciężkiego przedmiotu trudniej zatrzymać niż ruch lekkiego, a na przykład kamień można rzucić dalej niż pióro, to świadczy to o tym, że „im więcej jest materii, tym intensywniej i więcej można wtłoczyć impetusu w dane ciało". Buridan uzyskuje teraz proste wyjaśnienie wzrostu prędkości ciał spadających:

Przyjęte rozwiązanie wyjaśnia także przyczynę ciągłego nasilania się naturalnego ruchu ciał ciężkich do dołu. Na początku bowiem sama siła ciężkości była przyczyną ruchu, dlatego powodowała wolniejszy ruch. Lecz w trakcie ruchu siła wtłaczała w to ciało impetus, który wraz z nią porusza ciało i dlatego ruch staje się szybszy. Im ruch staje się szybszy, tym impetus staje się większy; obserwuje się przeto stały wzrost prędkości (Buridan 2000: 273).

Zwolenników teorii siły nabytej dzielił spór o to, czy impetus maleje sam przez się, czy też pod wpływem oporów ośrodka i ciężkości ciał. Nie sposób go było rozstrzygnąć doświadczalnie, ponieważ wszystkie ciała wykazywały naturalną skłonność do ruchu w górę lub w dół, a w swoich ruchach natrafiały na 
przeszkody. I tu Buridan znajduje pewien argument, choć dzieje się to za cenę rozciągnięcia - wbrew arystotelesowskiej tradycji - obowiązywania praw fizyki na sfery niebieskie:

Bóg po stworzeniu świata poruszył każde ciało niebieskie wedle swojej woli i przez to poruszenie wtłoczył w nie impetus poruszający je bez konieczności dalszego poruszania. [...] Owe impetusy raz wtłoczone w ciała niebieskie później nie przestawały działać, jako że nie ulegały zniszczeniu, ponieważ ciała niebieskie nie posiadały skłonności do innego ruchu i ponieważ ten ruch nie napotykał oporu powodującego zniszczenie lub zmniejszenie ich impetusu (Buridan 2000: 273).

Idee Buridana rozwijał w drugiej połowie XIV w. Mikołaj z Oresme (tłumacz Arystotelesa na francuski). Wykazał przede wszystkim, że z punktu widzenia fizyki arystotelesowskiej wzbogaconej o teorię impetusu można przyjąć, że Ziemia wiruje ruchem dobowym wokół osi, podczas gdy sfera gwiazd jest nieruchoma. Wyprowadził też wzór - sporządzając wykres prędkości w zależności od czasu w układzie, który później nazwano „kartezjańskim” - na drogę przebytą ruchem jednostajnie przyspieszonym. We współczesnych oznaczeniach: $s=\left(v_{p}+v_{k}\right) t / 2$, gdzie $v_{p}-$ prędkość początkowa, $v_{k}-$ prędkość końcowa, $t$ - czas trwania ruchu.

\section{UMYSŁ PUSTY NIE SPOSTRZEGA I NIE MYŚLI}

Splot czynników społecznych, najczęściej niekorzystnych dla rozwijania naukowych stylów myślowych, sprawil, że naszkicowany tu rozwój idei nabytej siły poruszającej trwał przez piętnaście wieków. A raczej ta idea wracała co jakiś czas, by zniknąć, a potem odrodzić się po kilku stuleciach. Co ważne, tylko teoria impetusu miała taką historię: była to jedyna koncepcja rozwijana w celu pogodzenia arystotelesowskiej fizyki z szeregiem anomalnych dla niej zjawisk znanych z codziennego doświadczenia.

Czy to, że - w ramach arystotelesowskiego obrazu świata - teoria impetusu nie miała konkurentki, należy tłumaczyć brakiem wyobraźni uczonych dawnych wieków? Sądzę, że to raczej zasady fizyki Arystotelesa nie pozwalały na sformułowanie innej teorii. Przypomnijmy: czynnik poruszający mógł zgodnie z tymi zasadami działać od wewnątrz (w przypadku ruchów naturalnych) bądź od zewnątrz (w przypadku ruchów wymuszonych). Od zewnątrz na rzucony kamień mogłoby działać tylko powietrze, ponieważ z niczym innym w trakcie lotu pocisk się nie styka. Ale codzienne doświadczenia przekonywały, że powietrze ruchów ciał nie podtrzymuje. Skoro tak, to pozostawało przyjąć, że czynnik poruszający działa w takich przypadkach od wewnątrz. 
Dalszą drogę wskazywały wyniki prostych obserwacji: nieożywione ciało nieruchome samo się nie poruszy, ale raz poruszone trwa w ruchu przez pewien czas. A zatem - znów przywołując podstawowe zasady fizyki Arystotelesa wewnętrzny czynnik poruszający jest nabyty, przekazany ciału przez pierwotnego, zewnętrznego sprawcę ruchu. Gdy dodamy do tego przytoczone wyżej prawo dla ruchów wymuszonych (2), wynika stąd, że impetus jest proporcjonalny do iloczynu ilości materii, z jakiej ciało jest zbudowane, i prędkości ruchu. Teoria impetusu została zatem sformułowana $\mathrm{w}$ ramach arystotelesowskiego obrazu świata, na podstawie wyników prostych obserwacji.

Jeśli teraz utożsamimy ilość materii z Newtonowską masą, to łatwo będzie ulec złudzeniu, że impetus Buridana jest tym samym co pęd nowożytnej fizyki. Jednak pęd to miara, rzec by można, ilości ruchu, natomiast impetus był przyczyna ruchu. Te style myślowe są niewspółmierne w sensie Ludwika Flecka i Thomasa Kuhna i żadne powierzchowne analogie tego nie zmienią. A jednak wiele wskazuje na to, że - historycznie rzecz biorąc - mechanika klasyczna wyrosła z mechaniki arystotelesowskiej uzupełnionej przez teorię impetusu. I temu trzeba się teraz przyjrzeć.

Wciąż wielu filozofów nauki jest naiwnymi falsyfikacjonistami, a w najlepszym razie zwolennikami Kuhnowskiego modelu rewolucji naukowych. Ci pierwsi myślą jakoś tak: naukowcy wymyślają teorię i przez pewien czas udanie ją stosują. Gdy natrafiają na doświadczenie falsyfikujące, to ci, którzy są racjonalni (a taka jest większość), odrzucają teorię i, od samych podstaw, wymyślają nową. Ci drudzy zdają sobie sprawę z tego, że w obliczu anomalii można teorię ratować za pomocą hipotez ad hoc i że tak naukowcy normalni zwykle czynią. Ale dodają, że gdy anomalii przybywa i zyskują one na znaczeniu, to grupa młodych badaczy ma poczucie kryzysu i zaczyna, prowadzone po omacku, badania nadzwyczajne. Wreszcie któryś z nich wpada - nie wiadomo w jaki sposób - na nowy pomysł i tym samym dostarcza nowych wzorców uprawiania nauki. Takie rewolucyjne zmiany są, podkreśla Kuhn, holistyczne, a zatem:

Nie mogą zostać dokonane po kawałku, krok po kroku i pod tym względem są przeciwieństwem zmian normalnych czy kumulatywnych, takich jak na przykład odkrycie prawa Boyle'a (Kuhn 2003: 30).

O tym, że nie można postępować ani według przepisów falsyfikacjonisty, ani w sposób naszkicowany przez Kuhna, pisał Ludwik Fleck:

Niemożliwe jest ahistoryczne, oderwane od historï poznawanie, podobnie jak niemożliwe jest poznawanie asocjalne, dokonywane przez izolowanego badacza. „Umysł pusty” nie postrzega, nie porównuje, nie uzupełnia, nie pogłębia: nie myśli (Fleck 1936: 35).

Aby myśleć, trzeba przyswoić sobie styl myślowy wytworzony przez pewną wspólnotę. Ten styl z jednej strony umożliwia nam myślenie, a z drugiej wy- 
twarza myślowe przymusy. To lektura pism Arystotelesa i jego komentatorów pobudzała kolejne pokolenia uczonych do dociekań i dociekania te ukierunkowywała. Odrzucenie tego stylu myślowego - czy to w wyniku racjonalnej oceny falsyfikacjonisty, czy w stanie psychologicznego kryzysu - wiodłoby nie do nowych, rewolucyjnych badań, lecz do zaniku zainteresowań ruchem ciał. Przecież na całej Ziemi, w ciągu wielu wieków, nikt nie zastanawiał się nad naturą ruchów i prawami, jakie nimi rządzą, poza wąskim gronem czytelników Arystotelesa i komentarzy do jego pism. Żadne teksty tego rodzaju nie powstały w istniejących od co najmniej trzech tysięcy lat cywilizacjach Indii albo Chin - a przecież Chińczycy dokonali szeregu znakomitych wynalazków technicznych.

Jednostka myśli - powtórzmy to nieco inaczej - gdy stosuje w pewnych okolicznościach styl myślowy wytworzony przez taką czy inną wspólnotę. Wszyscy myśliciele wspomniani wyżej stosowali zasady arystotelizmu, stopniowo przy tym arystotelizm przebudowując.

Można by spytać, dlaczego budowy systemu mechaniki klasycznej nie rozpoczęto od prac Archimedesa. Jego O równowadze plaszczyzn i $O$ cialach plywajacych to teksty naukowe $\mathrm{w}$ dzisiejszym tego słowa znaczeniu (i co warto podkreślić, dotyczą nie ruchów ciał, lecz właśnie sytuacji, gdy ruch ustaje). Tymczasem trudno uznać fizykę Arystotelesa za naukową. Myślę, że prace Archimedesa nie ukierunkowały badań głównie dlatego, że dla większości uczonych europejskich XIV w. były zbyt wyrafinowane matematycznie. Wspomniani kalkulatorzy oksfordzcy z tak zaawansowaną matematyką sobie radzili, ale było ich niewielu - i fizyki wychodzącej od idei Archimedesa nie zbudowali. Można się zastanawiać, czy i w jakim stopniu taka fizyka byłaby inna niż ta, którą sformułował Newton.

\section{O PRZEBIEGU REWOLUCJI NAUKOWYCH}

W swojej książce (Sady 2020) pokazałem, że rewolucje relatywistyczna (RR) i kwantowa (RK) w fizyce zostały dokonane przez trzy pokolenia uczonych. $\mathrm{W}$ pierwszym pokoleniu, badając pewne zjawiska zgodnie z zasadami mechaniki klasycznej, uzyskano twierdzenia teoretyczne rozsadzające od wewnątrz spójność zastanego systemu. W drugim pokoleniu teoretycy próbowali jednocześnie stosować prawa „stare” i „nowe”. W trzecim pokoleniu użyto „nowych” praw jako równań autonomicznych, nieredukowalnych do praw mechaniki klasycznej.

Mówiąc językiem Imre Lakatosa (1995), w pierwszym pokoleniu wzbogacono - próbując rozszerzyć zakres udanych zastosowań programu badawcze- 
go na nowo odkryte zjawiska - zastany program badawczy o nowy fragment pasa ochronnego, w drugim usiłowano stosować równania twardego rdzenia i tego nowego fragmentu jednocześnie, w trzecim ów fragment pasa ochronnego zaczął funkcjonować jako nowy twardy rdzeń. Na żadnym etapie naukowcy nie przystępowali do badań z pustymi umysłami: zawsze to, co wcześniej ustalili inni, prowadziło ich do badań eksperymentalnych i dociekań teoretycznych oraz te badania i dociekania ukierunkowywało.

\section{JAK PRZEBIEGŁA REWOLUCJA NEWTONOWSKA W FIZYCE?}

Powstaje pytanie, czy rewolucja newtonowska przebiegła według podobnego schematu co rewolucje relatywistyczna i kwantowa. Oczywiście skala czasowa była w jej przypadku nieporównanie dłuższa: od Filopona do Newtona upłynęło ponad jedenaście wieków, a nie sześć dziesięcioleci, jakie dzieli Maxwella od Einsteina, a Boltzmanna od Heisenberga, Schrödingera i Diraca. Nie ma w tym nic dziwnego, zważywszy okoliczności historyczne, w jakich to wszystko się działo.

Jeśli chodzi o Filopona, Awicennę czy Buridana, to w gruncie rzeczy ich prace powtarzają tę samą myśl, trochę w XIV w. rozbudowaną, a przede wszystkim zastosowaną do opisania większej grupy zjawisk. Zaliczyć ich trzeba - przez analogię do schematów z poprzedniego paragrafu - do pierwszego pokolenia rewolucjonistów. Wyniki ich dociekań, prowadzonych w ramach arystotelesowskiego obrazu świata, rozbijały spójność tego obrazu. Z jednej strony, ciało znajdujące się $\mathrm{w}$ ruchu wymuszonym miało zatrzymać się po utracie kontaktu z poruszycielem, a z drugiej strony, miało pozostać w ruchu raz mu nadanym, być może - przy braku oporów środowiska - na zawsze. Ruchy naturalne miały przebiegać, z jednej strony, ze stałymi prędkościami zależnymi od ciężarów ciał, a z drugiej strony, miały być przyspieszone i od ciężarów nie zależeć. A wreszcie zarówno naturalna ciężkość, jak i siła zewnętrzna miały nie tyle utrzymywać ciało w ruchu ze stałą prędkością (tę rolę przejął impetus), ile zmieniać impetus, a tym samym zmieniać prędkość.

Na fazę drugą trzeba było czekać do początków XVII w. Nieco wcześniej Kopernik połączył heliocentryzm Arystarcha z technikami matematycznymi Ptolemeusza i uzyskał nowy model ruchów planet, w tym Ziemi. Dociekania Kopernika nie miały nic wspólnego z mechaniką. Akceptacja modelu heliocentrycznego, w którym Ziemia została usunięta ze środka świata i wprawiona w ruch, wymagała jednak zbudowania nowej teorii ruchów cial. Zabrali się za to pierwsi znaczący zwolennicy kopernikanizmu: Galileusz, Kepler i Kartezjusz. 
Dodać do tego trzeba prace Torricellego, Pascala, Huygensa, Boyle'a, Borellego i jeszcze przynajmniej kilku uczonych. Stosowali oni jednocześnie twierdzenia czerpane z klasycznego arystotelizmu, łącznie z teorią impetusu, do czego dochodzily pitagoreizm i platonizm, ponownie wprowadzone na rynek idei w XVI w. A że tego wszystkiego na raz stosować się nie dało, poszczególni uczeni stosowali różne podzbiory znanych twierdzeń. Omówienie ich prac wymagałoby napisania oddzielnego artykułu.

Skończmy natomiast ten tekst paroma uwagami o tym, czego dokonał Robert Hooke, a co matematycznie opracował Newton. Uważam, że ich dokonanie sprowadzało się do rezygnacji z zasady, że wszystko, co się porusza, jest przez coś poruszane. Tym samym impetus stawał się zbędny (dokładnie to samo napisał Einstein w 1905 o eterze, wcześniej jednym z podstawowych składników fizycznego obrazu świata). Zachowali natomiast wspomniane konsekwencje fizyki Arystotelesa wzbogaconej o teorię impetusu. To, co było wnioskami, podnieśli do rangi samodzielnych zasad. Po czym te zasady zastosowali do analizy ruchów planet. Przyjrzyjmy się temu bliżej.

Zasadniczą rolę odegrało Buridanowskie twierdzenie, że ruch raz nadany ciału trwa, przy nieobecności oporów środowiska i innych przeszkód, bez końca ze stałą prędkością. Jeśli chodzi o tor, po jakim przebiegają ruchy, nazwane teraz bezwładnymi, to wchodziły w grę okrąg albo linia prosta: tylko te dwie linie są pozbawione punktów wyróżnionych. Obie możliwości zostały wypróbowane przez uczonych pierwszej połowy XVII w.: okrąg przez Galileusza, a linia prosta przez Kartezjusza. Spór o to, które rozwiązanie wybrać, nie był rozstrzygalny ani doświadczalnie, ani teoretycznie. Wybór był dowolny. Hooke wybrał po prostu zasadę bezwładności prostoliniowej.

Rozważmy teraz drugą ze wspomnianych konsekwencji teorii impetusu: działająca na ciało siła zewnętrzna zmienia jego impetus - równy iloczynowi ilości materii, z której jest ono zbudowane, i prędkości. Opuśćmy słowo „impetus”, nazwijmy ilość materii „masą”, a otrzymamy: siła zewnętrzna jest równa zmianie iloczynu masy i prędkości. Ta nowa definicja siły zastosowana do opisu zjawisk staje się drugą zasadą mechaniki klasycznej.

Już Buridan próbował stosować te same prawa do ruchów ciał niebieskich i ziemskich, podobnie postępowali Galileusz i Kartezjusz. Jeśli zasadę bezwładności prostoliniowej zastosować do ruchów planet, to z niej, z praw Keplera i z nowej definicji siły wynika, że na każdą z planet działa siła skierowana ku Słońcu, odwrotnie proporcjonalna do kwadratu odległości, która w danej chwili dzieli Słońce i tę planetę. Hooke był w stanie wywnioskować to w sposób przybliżony, Newton podał matematyczne wyprowadzenie ścisłe. Od tej chwili zaczął powstawać system teoretyczny w pełni niezależny od systemu fizyki Arystotelesa. Mało tego, oba systemy były niewspółmierne: operowały różnymi 
językami, a nawet jeśli używały tych samych symboli, to w różnych znaczeniach. Przy przejściu między nimi zmieniały się metody badań i kryteria akceptacji twierdzeń. Fizycy arystotelesowski i newtonowski, patrząc z tego samego miejsca w tym samym kierunku, widzieli niekiedy coś innego. Tym bardziej nie można w duchu Rovellego czy Grygiela traktować fizyki Arystotelesa jako szczególnego przypadku mechaniki klasycznej.

A mimo to obie fizyki łączy historyczna ciągłość. Na żadnym etapie rozwoju naukowcy nie zostawali z pustymi umysłami i nie próbowali stworzyć czegoś z niczego. Zasady mechaniki klasycznej pojawily się jako wnioski z zasad fizyki arystotelesowskiej i zbudowanej w jej ramach teorii impetusu, po czym podniesione do roli samodzielnych zasad oderwały się od swych źródeł, by dać początek nowemu programowi badawczemu.

\section{BIBLIOGRAFIA}

Arystoteles (1990), Fizyka, tłum. K. Leśniak [w:] Dzieła wszystkie, t. 2, Warszawa: Państwowe Wydawnictwo Naukowe, 23-204.

Arystoteles (1990), O niebie, tłum. P. Siwek [w:] Dzieła wszystkie, t. 2, Warszawa: Państwowe Wydawnictwo Naukowe, 232-338.

Arystoteles (1990), O powstawaniu i niszczeniu, tłum. L. Regner [w:] Dzieła wszystkie, t. 2, Warszawa: Państwowe Wydawnictwo Naukowe, 353-424.

Bodnar I. (2018), Aristotle's Natural Philosophy [w:] The Stanford Encyclopedia of Philosophy (Spring 2018 Edition), E. N. Zalta (ed.), https://stanford.io/3fYEOXT.

Buridan J. (2000), Subtilissimae quaestiones super octo Physicorum libros Aristotelis, fragm. w wyd. pol. Dzięki czemu porusza się przedmiot rzucony, tłum. M. Gensler, D. Gwis, E. Jung-Palczewska [w:] Wszystko to ze zdziwienia. Antologia tekstów filozoficznych z XIV w., E. Jung-Palczewska (red.), Warszawa: Wydawnictwo Naukowe PWN, 267-280.

Clagett M. (1955), Science of Mechanics in the Middle Ages, Madison: University of Wisconsin Press.

Crombie A. C. (1960), Nauka średniowieczna i początki nauki nowożytnej, tłum. S. Łypacewicz, t. 1 i 2, Warszawa: Instytut Wydawniczy PAX.

Duhem P. (1913-1959), Le système du monde, histoire des doctrines cosmologiques de Platon à Copernic, 10 tomów, Paris: Hermann.

Fleck L. (1936), Zagadnienie teorii poznawania, „Przegląd Filozoficzny” 39, 3-37.

Grant E. (1996), Średniowieczne podstawy nauki nowożytnej, tłum. T. Szafrański, Warszawa: Prószyński i S-ka.

Grygiel W. (2020), Mechanika arystotelesowska a wspótczesna fizyka. Na tropach ciągłości wewnętrznej logiki rozwoju nauki, „Filozofia Nauki” 28(1) [109], 5-24. https://doi.org/ 10.14394/filnau.2020.0001

Heller M. (1993), Fizyka ruchu i przestrzeni, Warszawa: Wydawnictwo Naukowe PWN.

Jones A., Taub L. (eds.) (2018), Cambridge History of Science, vol. 1, Ancient Science, Cambridge: Cambridge University Press. https://doi.org/10.1017/9780511980145 
Kuhn T. S. (2003), Czym sq rewolucje naukowe? [w:] tenże, Droga po „Strukturze”, thum. S. Amsterdamski, Warszawa: Sic!, 17-33.

Lakatos I. (1995), Falsyfikacja a metodologia naukowych programów badawczych [w:] Pisma z filozofii nauk empirycznych, tłum. W. Sady, Warszawa: Wydawnictwo Naukowe PWN, 3-169.

Lindberg D. C., Shank M. H. (2013), Cambridge History of Science, vol. 2, Medieval Science, Cambridge: Cambridge University Press. https://doi.org/10.1017/CHO9780511974007

Reale G. (1992), Historia filozofii starożytnej, t. II, Platon i Arystoteles, tłum. E. I. Zieliński, Lublin: KUL 2001.

Rovelli C. (2015), Aristotle's Physics: A Physicist's Look, „Journal of the American Philosophical Association" 1, 23-40. https://doi.org/10.1017/apa.2014.11

Sady W. (2020), Struktura rewolucji relatywistycznej i kwantowej $w$ fizyce, Kraków: Universitas.

Wróblewski A. K. (2006), Historia fizyki, Warszawa: Wydawnictwo Naukowe PWN. 